\title{
Correlation of Nutrition Education Model for Pregnant Women In Industrial Areas To Increase Knowledge of Nutrition, Nutritional Behavior, and Hemoglobin Levels of Pregnant Women
}

\author{
Lasiyati Yuswo Yani*, Raras Merbawani, Asef Wildan Munfadlila \\ STIKes Bina Sehat PPNI Mojokerto, Indonesia \\ *yuswoyani@gmail.com
}

\begin{abstract}
Mojokerto is an industrial city which accounts for as much as $40 \%$ of the total female employees of reproductive age in the East Java region. The health status of pregnant women in industrial areas is something that must be considered in order to produce a superior Indonesian generation.

The research design used the "Quasi-experimental pre post design" method. The sample of this study was 51 pregnant women in industrial areas. Treatment is in the form of nutrition education for pregnant women after the mother has confirmed knowledge of knowledge, nutritional behavior and $\mathrm{Hb}$ (hemoglobin) levels.

The results showed that the knowledge of pregnant women increased $73 \%$ after increasing behavior, $78 \%$ increased behavior and increased mean $\mathrm{Hb}$ from 11.64 to 12.14

This study proves that the nutrition education model for pregnant women in industrial areas has a positive correlation with maternal nutritional knowledge, nutritional behavior and $\mathrm{Hb}$ levels of pregnant women.
\end{abstract}

Keywords : Nutrition Education Model, Knowledge, Behavior, Hb (Hemoglobin) Levels, Pregnant Women 


\section{STRADA Jurnal Ilmiah Kesehatan}

DOI: $10.30994 /$ sjik.v9i2.391

ISSN: 2252-3847 (print); 2614-350X (online)

Vol.9 No.2 November 2020 Page.990-997

\section{BACKGROUND}

Nutrition education is the basis for any program aimed at improving nutrition (1). Knowledge of proper nutrition and a balanced diet during pregnancy are considered important for the well-being of both mother and fetus (2). During pregnancy, nutritional problems can affect both the mother and the fetus, therefore special attention is needed. Inadequate diet during pregnancy can cause various nutritional deficiencies such as anemia. So proper nutrition is an important part of pregnancy that should not be neglected (3)

WHO estimates that the prevalence of anemia in pregnant women is $14 \%$ in developed countries and $51 \%$ in developing countries (4). The results of research in the Pulogadung industrial area showed that the prevalence of anemia among female workers was $32.1 \%$. Based on the BMI indicator, $23.2 \%$ of workers were aware of obesity and $61.6 \%$ of carbohydrate consumption was higher than the standard dietary allowance. The incidence of anemia is still relatively high even though iron folic acid supplementation programs are implemented in the world (5). Related to this phenomenon, Mojokerto has a potential industrial area for similar research to explore problems and find solutions in an effort to improve the health status of mothers, especially pregnant women.

Research conducted on working pregnant women showed $76.5 \%$ had anemia and $23.5 \%$ were not anemic. In contrast to pregnant women who do not work, this is because pregnant women who work, especially in factories, do not have enough free time to participate in health education. (6) The knowledge obtained by pregnant women who do not work has an effect on the lower incidence of anemia in pregnant women compared to mothers who work.

The strategy most often used to improve the nutritional status of pregnant women is nutrition education which emphasizes the quality of the mother's diet by increasing the variety of diets (7). The research that will be planned will try to carry out nutrition education for pregnant women which will further examine its effect on $\mathrm{Hb}$ levels and eating behavior of pregnant women in industrial areas.

\section{METHOD}

This research was conducted using a "Quasi-experimental" approach. To determine the effect of nutrition education on HB levels and food intake of pregnant women. At this stage the researchers provided nutrition education treatments to pregnant women, before being given treatment for pregnant women, they first carried out an $\mathrm{Hb}$ examination. After the treatment of pregnant women, observations were made to determine the knowledge and behavior patterns of pregnant women iron consumption and $\mathrm{Hb}$ examination.

The data obtained at the time of data collection were coded, edited, and tabulated. Furthermore, the data were processed using the SPSS test using the paired T-Test for pre and post data on the knowledge and behavior of the respondents. Meanwhile, for the pre and post treatment $\mathrm{Hb}$ level data, the Kolmogorov-smirov statistical test was performed

\section{RESULT}

Table 1. The level of knowledge of pregnant women before and after treatment

\begin{tabular}{lcccc}
\hline \multirow{2}{*}{ knowledge } & \multicolumn{2}{c}{ Before } & & After \\
\cline { 2 - 5 } & Frekuensi & Percentage & Frequency & Percentage \\
\hline poor & 18 & $35 \%$ & 0 & $0 \%$ \\
satisfactory & 26 & $51 \%$ & 14 & $27 \%$ \\
\hline
\end{tabular}




\section{STRADA Jurnal Ilmiah Kesehatan}

DOI: $10.30994 /$ sjik.v9i2.391

ISSN: 2252-3847 (print); 2614-350X (online)

Vol.9 No.2 November 2020 Page.990-997

$\begin{array}{lllll}\text { good } & 7 & 14 \% & 37 & 73 \%\end{array}$

The results of the analysis in table 1 show that after being given treatment there was an increase in good knowledge by $73 \%$ and no respondent had a lack of knowledge.

Table 2 The behavior of nutrition consumption in pregnant women before and after treatment

\begin{tabular}{lcccc}
\hline \multirow{2}{*}{ attitude } & \multicolumn{2}{c}{ Before } & & After \\
\cline { 2 - 5 } & Frekuensi & Percentage & Frequency & Frekuensi \\
\hline poor & 16 & $31 \%$ & 0 & $0 \%$ \\
satisfactory & 20 & $39 \%$ & 11 & $22 \%$ \\
good & 15 & $30 \%$ & 40 & $78 \%$ \\
\hline
\end{tabular}

The results of the analysis in Table 2 above show that after being given the nutrition education model, there was an increase in the consumption of appropriate nutrition by $78 \%$ and there were no respondents who behaved inappropriately.

Table $3 \mathrm{Hb}$ (hemoglobin) levels in pregnant women before and after treatment

\begin{tabular}{llccc}
\hline No & Variabel & Minimim & Maximum & Mean \\
\hline 1 & Hb before & 8,6 & 14,6 & 11,63 \\
2 & Hb after & 10 & 14,2 & 12,14 \\
\hline
\end{tabular}

The results of the analysis in table 3 show that after being given the nutrition education model, there was an increase in the average $\mathrm{Hb}$ level of 12.14

Table 4 The Effect of the Nutrition Education Model on the knowledge of pregnant women on nutrition consumption during pregnancy

\section{Ranks}

\begin{tabular}{|c|c|c|c|c|}
\hline & & $\mathrm{N}$ & $\begin{array}{l}\text { Mean } \\
\text { Rank }\end{array}$ & $\begin{array}{l}\text { Sum of } \\
\text { Ranks }\end{array}$ \\
\hline \multirow{4}{*}{$\begin{array}{l}\text { POST KNOWLEDGE - PRE } \\
\text { KNOWLEDGE }\end{array}$} & $\begin{array}{l}\text { Negative } \\
\text { Ranks }\end{array}$ & $0^{\mathrm{a}}$ & \multirow{4}{*}{21.50} & \multirow{4}{*}{903.00} \\
\hline & Positive Ranks & $42^{\mathrm{b}}$ & & \\
\hline & Ties & $9^{c}$ & & \\
\hline & Total & 51 & & \\
\hline
\end{tabular}

The analysis showed that 42 people experienced an increase in their level of knowledge and 9 people had no change in their level of knowledge.

\begin{tabular}{|l|r|}
\multicolumn{2}{c}{ Test Statistics $^{\mathbf{a}}$} \\
\hline Z & PENGETAHUAN_POST - PENGETAHUAN_PRE \\
Asymp. Sig. (2-tailed) & $-6.132^{\mathrm{b}}$ \\
.000 \\
\hline
\end{tabular}

The results of the SPSS output above, the p-value of $0.000<\alpha$, it can be concluded that $\mathrm{H} 0$ is rejected, meaning that there is an effect of the nutrition education model on the level of knowledge of pregnant women on nutritional consumption during pregnancy. 


\section{STRADA Jurnal Ilmiah Kesehatan}

DOI: $10.30994 /$ sjik.v9i2.391

ISSN: 2252-3847 (print); 2614-350X (online)

Vol.9 No.2 November 2020 Page.990-997

Table 5 The influence of the nutrition education model on the behavior of maternal nutrition consumption during pregnancy

\begin{tabular}{|ll|l|l|l|}
\hline & Ranks & $\begin{array}{l}\text { Mean } \\
\text { Rank }\end{array}$ & $\begin{array}{l}\text { Sum of } \\
\text { Ranks }\end{array}$ \\
\hline & $\begin{array}{l}\text { Negative } \\
\text { Ranks }\end{array}$ & $0^{\mathrm{a}}$ & .00 & .00 \\
POST BEHAVIOR - & Positive Ranks & $36^{\mathrm{b}}$ & 18.50 & 666.00 \\
PRE BEHAVIOR & Ties & $15^{\mathrm{c}}$ & & \\
& Total & 51 & & \\
\hline
\end{tabular}

The analysis showed that 36 people experienced an increase in their nutritional consumption behavior during pregnancy and 15 people had no change in their nutritional consumption behavior during pregnancy

\section{Test Statistics ${ }^{\mathrm{a}}$}

\begin{tabular}{|l|r|}
\hline & $\begin{array}{r}\text { POST BEHAVIOR - PRE } \\
\text { BEHAVIOR }\end{array}$ \\
\hline Z & $-5.687^{\mathrm{b}}$ \\
$\begin{array}{l}\text { Asymp. Sig. (2- } \\
\text { tailed) }\end{array}$ & .000 \\
\hline
\end{tabular}

The results of the table analysis of the p-value of $0.000<\alpha$, it can be concluded that $\mathrm{HO}$ is rejected, meaning that there is an effect of the nutritional education model on nutrition consumption behavior during pregnancy.

Effect of nutrition education on hemoglobin levels of pregnant women Table 6 Results of testing for normality of $\mathrm{Hb}$ level data for pregnant women before and after treatment

One-Sample Kolmogorov-Smirnov Test

\begin{tabular}{ccccccc}
\hline \multirow{2}{*}{ Variable } & \multicolumn{2}{c}{ Mean } & \multicolumn{3}{c}{ Std. Deviation } & \multicolumn{2}{c}{$p$ value } \\
\cline { 2 - 7 } & Before & After & Before & After & Before & after \\
\hline Level $\mathrm{Hb}$ & 11,63 & 12,141 & 1,361 & 0,851 & 0,909 & 0,303 \\
\hline
\end{tabular}

The results of the data normality test analysis using the Kolmogorov-Smirnov test, $\mathrm{p}$ value $>0.05$, it can be concluded that the data above is normally distributed.

Table 7 The results of testing the hypothesis of the effect of nutrition education on Hb levels

\begin{tabular}{|c|c|c|c|c|c|c|c|}
\hline \multirow{2}{*}{ Variabel } & & \multicolumn{6}{|c|}{$\begin{array}{c}95 \% \text { Confidence } \\
\text { Interval }\end{array}$} \\
\hline & & Mean & $\begin{array}{c}\text { Std. } \\
\text { Deviation }\end{array}$ & Lower & Upper & $t$ & $p$ value \\
\hline level $\mathrm{Hb}$ & $\begin{array}{l}\text { Before - } \\
\text { after }\end{array}$ & 0,509 & 0,694 & $-0,705$ & $-0,314$ & $\begin{array}{c}- \\
5,241\end{array}$ & 0,000 \\
\hline
\end{tabular}




\section{STRADA Jurnal Ilmiah Kesehatan}

DOI: $10.30994 /$ sjik.v9i2.391

ISSN: 2252-3847 (print); 2614-350X (online)

Vol.9 No.2 November 2020 Page.990-997

The results of the paired t test analysis showed that the $\mathrm{p}$ value was $0.00<\alpha$, it was concluded that $\mathrm{H} 0$ was rejected, meaning that there was an influence on the nutrition education model on the hemoglobin level of pregnant women

\section{DISCUSSIONS}

This study shows that a nutritional education model and diet plan based on iron-rich foods during pregnancy are shown to improve knowledge, nutrition consumption behavior and increase hemoglobin levels. Similar results were reported by a randomized study conducted at the University of Ghana showing that nutrition education that emphasizes consumption of iron-rich foods is positively associated with increased hemoglobin levels. (8). A quasi-experimental study conducted by Al-tell MA et al, (2010) A quasiexperimental study conducted by (9) . Likewise, in a pre-test post-test study on pregnancy conducted by Garg \& Kashyap (2006), individual counseling significantly increased mean hemoglobin levels in pregnant women $(0,97$ vs $1,58, \mathrm{P}<0,001)(10)$. Likewise, a randomized control trial among pregnant Nepalese women, the educational program saw only significantly higher changes in hemoglobin $(0,23 \mathrm{gm} / \mathrm{dl})$ compared to the control group $(\mathrm{P}<0.01)(11)$. While a randomized control trial conducted in Greece did not show a significant effect of nutrition education and counseling on hemoglobin levels in the intervention group compared to the control group (12).

A review of previous randomized control trials and quasi-experimental studies reported substantial and significant effects when nutritional education and counseling was provided with nutritional supplements, mostly via micronutrients, compared to nutrition education alone. (13). The Nepal Demographic and Health Survey report shows that only $42 \%$ of women taking the recommended dose of iron during pregnancy and $41 \%$ of women aged 15 to 49 are anemic (14). Thus, adherence to iron supplementation is still low in pregnant women in Nepal. According to the Multi-Sectoral Nutrition Plan II, Nepal has a target to reduce the prevalence of anemia among women of reproductive age by $50 \%$ in line with the Sustainable Development Goals. (14). Counseling on nutrition education and a diet plan based on iron-rich foods for pregnant women can be effective strategies to reduce anemia among pregnant women.

The nutrition education intervention and diet plan based on iron-rich foods were significantly associated with improved maternal nutritional knowledge scores of anemia and intake of iron-rich foods in the intervention group compared to the control group $(66 \%$ vs $24.1 \%$ ). A randomized study conducted at a Ghanaian university reported that a significant increase in knowledge was demonstrated by the intervention group at the end of the intervention period (8). Studies conducted in Ethiopia revealed that the knowledge of pregnant women about nutrition during pregnancy increased significantly after the provision of nutrition education and special dietary practices (15). The intervention study design was carried out in Kalyobia Governorate (Moshtoher, KafrShoukr, and Kaha) (n = 200). The results showed $78 \%$ of pregnant women had achieved a good nutritional knowledge score after the intervention. (16). However, most of the counseling conducted during antenatal visits tends to be general in nature in the Nepalese context. Our findings suggest that pregnant women who have good nutritional knowledge can increase hemoglobin levels. Thus, nutrition education and counseling during antenatal visits can increase maternal nutritional knowledge about iron-rich foods. Similar results were reported by another study conducted, an intervention study that after a nutrition education session, there was a significant increase in the nutritional knowledge score that could help prevent anemia. (17). 


\section{STRADA Jurnal Ilmiah Kesehatan}

DOI: $10.30994 /$ sjik.v9i2.391

ISSN: 2252-3847 (print); 2614-350X (online)

Vol.9 No.2 November 2020 Page.990-997

Another study conducted by Kafatos AG et al, indicated that nutritional counseling during pregnancy can increase food intake and increase maternal weight. (12). The results of this study indicated that pregnant women who received nutrition education and an ironbased diet experienced a significant increase in their consumption levels of red meat, fish liver, vitamin C-rich fruits, dairy products, eggs and dark green vegetables compared to controls. group. The study conducted by Liu N et al, (2009) also showed that fruit consumption increased in the intervention group than in the control group (18). Pregnant women in the intervention group reflected a change in behavior by practicing a minimum dietary intake of 3 or more (19). Nutrition education and counseling have been found in other studies to improve maternal diet including dietary practices and consumption of macro and micro nutrients (8)(20). Micronutrient deficiencies can lead to poor maternal health outcomes and pregnancy-related complications (21). Brough L et al, (2010) showed that increasing consumption of micronutrients in pregnancy can improve the nutritional status of pregnant women. Research conducted by E. Emilia (2009) also revealed the need to implement nutrition education as an effort to change behavior to improve nutrition (22). Health education with the Model Information Motivation Behavior Skill (IMB) approach plays a role in increasing knowledge and patterns of consumption of vegetables and fruits in pregnant women. (23).

\section{CONCLUSION}

The nutrition education model for pregnant women in industrial areas has a positive correlation with the increase in knowledge of pregnant women. The nutrition education model for pregnant women in industrial areas has a positive correlation with the increase in nutritional behavior of pregnant women. The nutrition education model for pregnant women in industrial areas has a positive correlation with the increase in Hb levels of pregnant women

\section{LIMITATIONS}

Our study has several limitations. Our study sample size is insufficient because the findings cannot be generalized to a wider population. Adherence to nutritional education and diet plans based on iron-rich foods was not assessed in this study. Only hemoglobin levels were measured so we could not assess the differentiation of anemia, such as iron deficiency, nutrition, genetics, and infectious anemia in this study. There is a possibility of bias because there was no control group in this study.

\section{ACKNOWLEDGMENT}

YKWP-PNI Kab. Mojokerto and all his staff, the Head of the PPNI Healthy Development STIKes and all the structural members, Prof. Dr. Doekandar Mojosari, UPT Puskesmas Ngoro and all staff. Village midwives, health and community cadres in Ngoro, Sedati, Lolawang and Kembang Sri Villages

\section{REFERANCE}

1. da Silva Lopes K, Ota E, Shakya P, Dagvadorj A, Balogun OO, Peña-Rosas JP, et al. Effects of nutrition interventions during pregnancy on low birth weight: an overview of systematic reviews. BMJ Glob Heal [Internet]. 2017 Sep 22;2(3):e000389. Available from: http://www.ncbi.nlm.nih.gov/pmc/articles/PMC5623264/

2. Sunuwar DR, Sangroula RK, Shakya NS, Yadav R, Chaudhary NK, Pradhan PMS. Effect of nutrition education on hemoglobin level in pregnant women: A quasi- 


\section{STRADA Jurnal Ilmiah Kesehatan}

DOI: $10.30994 /$ sjik.v9i2.391

ISSN: 2252-3847 (print); 2614-350X (online)

Vol.9 No.2 November 2020 Page.990-997

experimental study. PLoS One. 2019;14(3):e0213982.

3. Fallah F, Pourabbas A, Delpisheh A, Veisani Y, Shadnoush M. Effects of nutrition education on levels of nutritional awareness of pregnant women in western Iran. Int $\mathbf{J}$ Endocrinol Metab. 2013;11(3):175-8.

4. McLean E, Cogswell M, Egli I, Wojdyla D, de Benoist B. Worldwide prevalence of anaemia, WHO Vitamin and Mineral Nutrition Information System, 1993-2005. Public Health Nutr [Internet]. 2009;12(4):444. Available from: http://www.journals.cambridge.org/abstract_S1368980008002401

5. Sihombing M, Riyadina W. Faktor-Faktor yang Berhubungan Dengan Anemia Pada Pekerja Di Kawasan Industri Pulo Gadung Jakarta. Media Penelit dan Pengemb Kesehat. 2009;19(3 Sept).

6. Purbadewi L, Ulvie YNS. Hubungan Tingkat Pengetahuan Tentang Anemia Dengan Kejadian Anemia Pada Ibu Hamil. J Gizi. 2013;2(1).

7. Nielsen JN, Gittelsohn J, Anliker J, O'Brien K. Interventions to improve diet and weight gain among pregnant adolescents and recommendations for future research. $\mathrm{J}$ Am Diet Assoc. 2006;106(11):1825-40.

8. Otoo G AY. Effect of nutrittion education with an emphasis on consumption of ironrich foods on hemoglobin levels of pregnant women in Ghana. FASEB J [Internet]. 2016;30(1). Available from: http://www.fasebj.org/doi/abs/10.1096/fasebj.30.1_supplement.410.2

9. El-guindi FK, Soliman NM E-NH. Effect of nutritional interventions on anemic pregnant womens health promotion model. Med J Cairo Univ. 2010;

10. Pediatr IJ. Effect of counselling on nutritional status during pregnancy. Indian JPediatr [Internet]. 2006;73(8):687-92. Available from: http://www.ncbi.nlm.nih.gov/pubmed/16936363

11. Adhikari K, Liabsuetrakul T PN. Effect of education and pill count on hemoglobin status during prenatal care in Nepalese women: A randomized controlled trial. J Obs Gynaecol Res [Internet]. 2009;35(3):459-66. Available from: http://www.ncbi.nlm.nih.gov/pubmed/19527383n

12. Kafatos AG, Vlachonikolis IG CC. Nutrition during pregnancy: the effects of an educational intervention program in Greece. Am J Clin Nutr [Internet]. 1989;50(5):970-9. Available from: http://www.ncbi.nlm.nih.gov/pubmed/2816804

13. Girard AW OO. Nutrition education and counselling provided during pregnancy: Effects on maternal, neonatal and child health outcomes. Paediatr Perinat Epidemiol. 2012;26(1):191-205.

14. Ministry of Health. New ERA, The DHS Program ICF. Nepal Demographic and Health Survey [Internet]. 2016. Available from: https://www.dhsprogram.com/pubs/pdf/FR336/FR336.pdf

15. Robertson N LB. Effect of individual dietetic intervention on gestational weight gain and associated complications in obese pregnant women. Aust N Z J Obs Gynaecol [Internet]. 2017; Available from: http://doi.wiley.com/10.1111/ajo.12711

16. Abd ElHameed H, Mohammed A AEHL. Effect of nutritional educational guideline among pregnant women with iron deficiency anemia at rural area in Kalyobia governorate. Life Sci J. 2012;9(2).

17. Nimbalkar PB, Patel JN, Thakor N PM. Impact of educational intervention regarding anaemia and its preventive measures among pregnant women: an interventional study. Int J Reprod Contraception, Obs Gynecol [Internet]. 2017;6(12):5317-21. Available from: https://www.ijrcog.org/index.php/ijrcog/article/view/3989 


\section{STRADA Jurnal Ilmiah Kesehatan}

DOI: $10.30994 /$ sjik.v9i2.391

ISSN: 2252-3847 (print); 2614-350X (online)

Vol.9 No.2 November 2020 Page.990-997

18. Liu N, Mao L, Sun X, Liu L, Yao P CB. The effect of health and nutrition education intervention on women's postpartum beliefs and practices: A randomized controlled trial. BMC Public Health. 2009;9.

19. Daniel S, Pu G, Gnanaraj S SE. Effect of nutrition education among pregnant women with low body mass index: a community based intervention. Int $\mathbf{J}$ Community Med Public Heal [Internet]. 2016;3(11):3135-9. Available from: https://www.ijcmph.com/index.php/ijcmph/article/viewFile/113/110

20. Adhikari BK, Koirala U, Lama S DP. Situation of Iron Deficiency and Its Management Prioritizing Dietary Intervention in Nepal. Nepal $\mathbf{J}$ Epidemiol [Internet]. 2012;2(2):182-90.

Available

from: http://www.nepjol.info/index.php/NJE/article/view/6573

21. Christian P. Iron Deficiency and Anemia Causes, Consequences, and Solutions [Internet]. International Nutrition. 2005. Available from: http://ocw.jhsph.edu/courses/InternationalNutrition/PDFs/Lecture5.pdf

22. Emilia E. Pendidikan gizi sebagai salah satu sarana perubahan perilaku gizi pada. J Tabularasa. 2009;6(2):161-74.

23. Farhati F, Resmana R, Nurhadianti D. Pendidikan Kesehatan dengan Pendekatan Model Information Motivation Behavior Skill (IMB) terhadap Peningkatan Pengetahuan dan Pola Konsumsi Sayur dan Buah pada Ibu Hamil. J Kesehat. 2019;10(3):320-8. 